bearing on one side a photograph of the speaker and on the other side bibliographical details of his scientific work, together with the complete text of the talk. The set is being offered at an inclusive charge of three dollars, and, at such a low price, may be recommended not only to teachers and students, but also to anyone interested in science in general.

\section{Co-ordination of Scientific Terminology}

Among the scientific questions which the International Institute of Intellectual Co-operation has been asked to examine is the co-ordination of scientific terminology. Various international organisations, including the Commission of Electro-technics and certain scientific unions, have undertaken, each in its respective sphere, the compilation of scientific or technical vocabularies. The different branches of science, however, constantly employ, and very often with a different meaning, terms which are common to all of them. It therefore appeared indispensable that the co-ordination of these terms should be undertaken. For this purpose, a Committee recently met at the International Institute of Intellectual Co-operation. It was composed of Prof. Cabrera (Madrid, chairman); Prof. Cotton (Paris), representing the International Union of Physics; Prof. Willstätter (Munich), Prof. Lowry (Cambridge), delegates of the International Union of Chemistry; Prof. Selys-Longchamps and Dr. Ledoux (Brussels), representing the Intermational Union of Biological Sciences ; and Prof. Lombardi (Rome), delegate of the International Union of Electrotechnics. The Committee invited the International Institute of Intellectual Co-operation to undertake the work of co-ordination in conjunction with the international organisations concerned.

\section{Fourteenth International Physiological Congress}

The Fourteenth International Physiological Congress will be held in Rome on Aug. 28-Sept. 3, as arranged; no change has taken place in the date fixed for it. The president of the Congress is Prof. Bottazzi of Naples, and the International Committee consists of Profs. Pavlov (Russia), Johansson (Sweden), Howell (United States), Frank (Germany), Lapicque (France), and A. V. Hill (Great Britain). The inaugural ceremony will be held in the Giulio Cesare Hall of the Campidoglio. The inaugural lecture will be given by Prof. A. V. Hill, and receptions will be given by the Governor of Rome and the Royal Academy of Italy. Foreign participants in the Congress will enjoy a reduction of fifty per cent for tickets taken, under certain conditions, on the Italian railways. In the near future, those who have already returned their applications for membership will receive further information, and a programme of the inaugural ceremony and other functions.

\section{Announcements}

IT is announced in Science of March 18 that Sir James Jeans has been made an honorary member of the Washington Academy of Sciences, in recognition of his contributions to the dynamical theory of gases, to cosmogony, and to astrophysics.
The William H. Nichols Medal for 1932 of the New York Section of the American Chemical Society was presented on March 1 to Prof. J. B. Conant, chairman of the division of chemistry in Harvard University, in recognition of his work in organic chemistry, particularly in the chemistry of chlorophyll.

Aт the annual general meeting of the Physical Society, held on March 18, the following officers were elected: President, Prof. A. O. Rankine; Secretaries, Dr. Ezer Griffiths (Business), Dr. Allan Ferguson (Papers) ; Foreign Secretary, Prof. O. W. Richardson; Treasurer, Mr. R. S. Whipple; Librarian, Dr. J. H. Brinkworth.

Applications are invited for the following appointments, on or before the dates mentioned :-A male assistant in the Department of Printed Books of the National Library of Wales-The Librarian, National Library of Wales, Aberystwyth (April 12). A registrar of the Wigan and District Mining and Technical College-The Principal, Wigan and District Mining and Technical College, Wigan (April 15). A director of education for the City of Sheffield-The Director of Education, Leopold Street, Sheffield (April 16). A Dickinson research travelling scholar in medicine; a Dickinson research surgery scholar; and a Dickinson research scholar in medicine, each at the Manchester Royal Infirmary-The Secretary to the Trustees, Royal Infirmary, Manchester (April 16). A head of the Commerce Department of the Wigan and District Mining and Technical College - The Principal, Wigan and District Mining and Technical College, Wigan (April 18). A full-time lecturer with degree, and a knowledge of general engineering or mining, at the County Technical Institute, Worksop-The Principal, County Technical Institute, Worksop (April 21). A junior scientific officer in an Admiralty establishment at Portsmouth - The Secretary of the Admiralty (C.E. Branch), Whitehall, S.W.1 (April 23). Probationary assistant naval constructors-The Secretary of the Admiralty (C.E. Branch), Whitehall, S.W.1 (April 30). An assistant in the Department of Forestry of the University College of North Wales-The Registrar, University College of North Wales, Bangor (May 9). A professor of physiology at the London Hospital Medical College-The Academic Registrar, University of London, South Kensington, S.W.7 (May 14). A head of the Mechanical and Electrical Engineering Department of the Harris Institute, Preston-The Principal, Harris Institute, Preston (June 1). An assistant lecturer in civil engineering, building construction and sanitary science at the Battersea Polytechnic--The Principal, Battersea Polytechnic, S.W.11. An assistant master for elementary engineering and metalwork at the Sawston Village CollegeThe Education Secretary, County Hall, Cambridge. A temporary junior assistant with first or second class honours in physics, or equivalent, at the Experimental Station, Porton, near Salisbury-The Chief Superintendent, Chemical Defence Research Department, War Office, 14 Grosvenor Gardens, S.W.1.

No. 3258, VoL. 129] 